\title{
MODERN COMPOSITE MATERIALS FOR SWITCHING AND WELDING EQUIPMENT. Information 1. POWDERED COMPOSITE MATERIALS
}

\author{
E.V. KHOMENKO, N.I. GRECHANYUK and V.Z. ZATOVSKY \\ I.M. Frantsevich Institute of Problems of Materials Science, NASU \\ 3 Krzhizhanovsky Str., 03142, Kiev, Ukraine. E-mail: homhelen@mail.ru
}

\begin{abstract}
The paper presents modern developments in the field of powdered composite materials of pseudoalloy type based on $\mathrm{Cu}(\mathrm{Ag})$ and refractory metals W ( $\mathrm{Mo}, \mathrm{Cr})$, used as electric contact materials and welding electrodes. Main requirements made of materials of arcing contacts and resistance welding electrodes are briefly described. Main data from world manufacturers on compositions and regulated characteristics of this material type are given, and main process schematics of their manufacturing are listed. Certain technological difficulties of producing nanodispersed composites are pointed out that slow down their production on an industrial scale. It is noted that application of mechanical alloying method during high-energy milling of powders allows producing copper, dispersion-strengthened by refractory oxides and carbides $\left(\mathrm{Al}_{2} \mathrm{O}_{3}\right.$, $\mathrm{TiO}_{2}, \mathrm{Cr}_{2} \mathrm{O}_{3}, \mathrm{SiO}_{2}$, etc.) with recrystallization temperature close to that of copper melting and higher level of electric conductivity, strength and oxidation resistance, compared to chromium and chromium-zirconium bronzes. 41 Ref., 5 Tables, 4 Figures.
\end{abstract}

Key words: copper-based powdered composite materials, switching and welding equipment

At present it is difficult to imagine an engineering field, not using composite materials. Their wide application area is due to high performance level, being greatly superior to that of metals and alloys, as well as a combination of high strength and stiffness, fatigue fracture resistance with high-temperature strength and wear resistance [1-3].

Powdered composite materials (PCM) of metal matrix type based on copper and silver, strengthened by particles of refractory metals and chemical compounds, have been the most widely accepted in switching and welding equipment. Owing to a unique combination of properties, metal-matrix $\mathrm{CM}$ are used as contacts and electrodes operating under the conditions of simultaneous impact of high temperatures, mechanical stresses, and impact loads in different gas media. Matrix provides a high level of heat- and electric conductivity, and refractory phase - high hardness, erosion, mechanical and thermal resistance. These systems belong to pseudoalloys, produced mostly by powder metallurgy methods. Pseudoalloy term is commonly understood as a heterogeneous system, represented by components, which do not interact or weakly interact with each other in a broad temperature range, thus preserving their individual properties in the mixture [4].

(c) E.V. KHOMENKO, N.I. GRECHANYUK and V.Z. ZATOVSKY, 2015
CM based on copper or silver and refractory metals of VIa group ( $\mathrm{Cr}, \mathrm{Mo}, \mathrm{W})$ have found application as arcing contacts for switching high (25 kA and higher) currents in high voltage networks (up to $570 \mathrm{kV}$ ) [5-8]. Arcing contacts are the most critical parts of switching devices, taking up the main impact of closing and opening electric arc [9-11]. For effective operation these contacts should have good heat- and electric conductivity, high melting and boiling temperatures, high values of electron work function and ionization potential, considerable fatigue strength and high-temperature oxidation resistance, low values of contact resistance, low solubility of gases and other properties [4, 10].

Metals with good conducting properties (Ag, $\mathrm{Cu}, \mathrm{Au}, \mathrm{Pt}$, etc.) are characterized by low melting and recrystallization temperatures, high susceptibility to welding, low strength and low thermal stability, resulting in their quite limited application. Such refractory metals, as W, Mo, Re, Ta, Cr, etc., featuring high mechanical characteristics, have insufficient heat and electric conductivity. Fusion of low-melting and refractory metals, usually, involves technological difficulties, associated with significant differences in their physico-chemical characteristics [12, 13]. Moreover, partial dissolution of elements in liquid and solid phases occurs at fusion that may lead to loss of their individual properties [14].

Production of powdered pseudoalloys is an example of effective application of powder metallurgy method, allowing regulation of material 


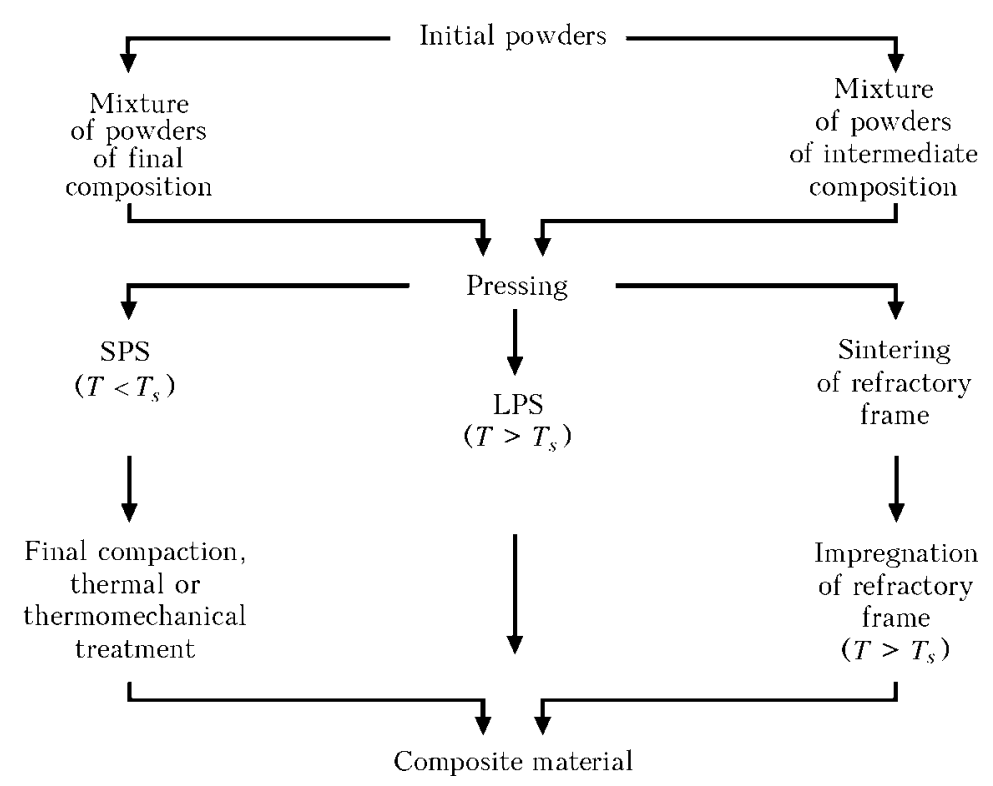

Figure 1. Technological schematic of producing Ag $(\mathrm{Cu})-\mathrm{W}(\mathrm{Mo}, \mathrm{Cr}) \mathrm{CM}\left(T_{s}-\right.$ low-melting phase melting temperature)

properties by quite cost-effective and relatively simple means, due to selection of initial raw material and technological manufacturing schematic.

Technology of producing these materials includes [1-17] the stages of powder mixing and pressing, subsequent heat treatment (sintering) and final compaction to achieve maximum density close to theoretical one (Figure 1).

Pre-compacted mechanical mixture of powders can be sintered in the solid state (SPS) or in the presence of the liquid phase (LPS).

SPS advantages consist in that composite composition is not limited by low-melting phase content. As a rule, however, maximum density cannot be achieved in one cycle, and deformational or thermodeformational treatment is required. LPS technology allows acceleration of the processes of component diffusion in the material and provides the possibility of its maximum compaction during sintering. Sintering atmosphere depends on item purpose, and, as a rule, is a reducing or degassing medium (hydrogen, vacuum). Such alloying additives as $\mathrm{Fe}, \mathrm{Co}, \mathrm{Ni}, \mathrm{Ti}, \mathrm{Zr}$, etc. (up to 1-3 wt.\%) are used to improve wetting of refractory phase surface by the liquid phase during LPS [4, 18, 19]. This technology limits liquid phase content (not more than 50 vol.\%) to prevent item shape loss. An optimum technological measure is impregnation by melts of $\mathrm{Al}$ $(\mathrm{Cu})$ or their alloys of refractory frame, formed with addition of low-melting component or without it (see Figure 1, on the right). This process does not require limitation of liquid phase volume, and provides the density, close to the theoretical one. Moreover, liquid phase excess at impregnation can be used as a transition conducting layer on the contact reverse surface for welding to the unit current-conducting components.

As regards CM, correlations are often found between contact performance and refinement of refractory phase particle size to micron and submicron dimensions [20-22]. In this connection, hot dynamic pressing is a promising technology of producing $\mathrm{Ag}(\mathrm{Cu})-\mathrm{W}(\mathrm{Mo}, \mathrm{Cr}) \mathrm{CM}$, at which mechanical mixture of powders of final composition is subjected to high-speed pressing and heat treatment in vacuum in one operation. Such combined treatment provides degassing of powders, preservation of their high dispersity, formation of highly-dense material of higher strength and hardness and satisfactory level of electric conductivity [23].

In production, $\mathrm{CM}$ technical characteristics are usually regulated as to their composition, density, specific electric resistance and hardness (Tables 1-3). Selection of material and technological production sequence is determined by contact service conditions. All the materials are characterized by a general tendency of increase of the characteristics of hardness and erosion resistance and lowering of heat- and electric conductivity with increase of refractory phase content. Nature of refractory filler and schematic of CM manufacturing also influence the nature of its property change.

Ag-WC CM are characterized by higher hardness and lower specific electric resistance, compared to $\mathrm{Ag}-\mathrm{W} \mathrm{CM}$ in a similar concentration range of matrix content. Here, the impregnation schematic provides high-density material with high values of hardness, heat- and electric conductivity, compared to materials produced by SPS schematic with final compaction (see Ta- 
INDUSTRIAL

Table 1. Main properties of $\mathrm{Ag}-\mathrm{W}, \mathrm{Ag}-\mathrm{WC}$ and $\mathrm{Ag}-\mathrm{Mo}$ composite materials (DODUCO materials [24])

\begin{tabular}{|c|c|c|c|c|c|}
\hline \multirow{2}{*}{ Material } & \multirow{2}{*}{ Ag content, wt. $\%$} & \multirow{2}{*}{ Density, $\mathrm{g} / \mathrm{cm}^{3}$} & \multicolumn{2}{|c|}{ Specific electric conductivity } & \multirow{2}{*}{ Hardness $H V 10$} \\
\hline & & & $\%$ IACS & $\mathrm{MSm}^{-1}$ & \\
\hline $\begin{array}{l}\text { AgW } 50 / 50 \\
\text { SIWODUR 50-1 }\end{array}$ & $48-52$ & $13.0-13.4$ & 45 & 26 & $120-140$ \\
\hline $\begin{array}{l}\text { AgW } 40 / 60 \\
\text { SIWODUR 60-1 }\end{array}$ & $38-42$ & $14.0-14.4$ & 41 & 24 & $140-160$ \\
\hline $\begin{array}{l}\text { AgW } 30 / 70 \\
\text { SIWODUR 70-1 }\end{array}$ & $28-32$ & $15.0-15.4$ & 34 & 20 & $160-190$ \\
\hline $\begin{array}{l}\text { AgW } 20 / 80 \\
\text { SIWODUR 80-1 }\end{array}$ & $18-22$ & $15.8-16.3$ & 31 & 18 & $180-230$ \\
\hline $\begin{array}{l}\text { AgWC } 60 / 40 \\
\text { SIWODUR C 40-1 }\end{array}$ & $58-62$ & $11.6-11.9$ & 41 & 24 & $130-160$ \\
\hline $\begin{array}{l}\text { AgWC } 50 / 50 \\
\text { SIWODUR C 50-1 }\end{array}$ & $48-52$ & $12.0-12.4$ & 38 & 22 & $140-170$ \\
\hline $\begin{array}{l}\text { AgWC } 40 / 60 \\
\text { SIWODUR C 60-1 }\end{array}$ & $38-42$ & $12.4-12.8$ & 36 & 21 & $150-180$ \\
\hline $\begin{array}{l}\text { AgWC 84/16C2 } \\
\text { SIWODUR C16/C2-2 }\end{array}$ & $80-84$ & 9.8 & 60 & 35 & 55 \\
\hline $\begin{array}{l}\text { AgWC } 73 / 27 \mathrm{C} 3 \\
\text { SIWODUR C16/C3-2 }\end{array}$ & $68-72$ & 9.6 & 36 & 21 & 50 \\
\hline $\begin{array}{l}\text { AgMo } 50 / 50 \\
\text { SILMODUR 50-1 }\end{array}$ & $48-52$ & $9.9-10.2$ & 34 & 20 & $120-140$ \\
\hline $\begin{array}{l}\text { AgMo } 40 / 60 \\
\text { SILMODUR 60-1 }\end{array}$ & $38-42$ & $9.9-10.2$ & 31 & 18 & $130-170$ \\
\hline $\begin{array}{l}\text { AgMo } 30 / 70 \\
\text { SILMODUR 70-1 }\end{array}$ & $28-32$ & $10.0-10.4$ & 29 & 17 & $140-180$ \\
\hline
\end{tabular}

ble 1). $\mathrm{W}-\mathrm{Cu} \mathrm{CM}$ are characterized by an essential improvement of strength properties at reduction of tungsten grain dimensions (see Table 2). Structure of $\mathrm{Ag}(\mathrm{Cu})-\mathrm{W}(\mathrm{Mo}, \mathrm{Cr})$ PCM is characterized by presence of two or more phases based on refractory and low-meting components with particles from submicron size up to $300-500 \mu \mathrm{m}$ (Figure 2). Depending on requirements to the level of heat- and electric conductivity, as well as erosion resistance and mechanical wear, $\mathrm{CM}$ can consist of conducting phase frame with refractory particles dispersed in it, or of refractory frame, the capillaries of which are filled with low-melting phase. Simultaneous existence of two interpenetrating frames of low-melting and refractory components is also possible.

Producing CM with ultradispersed particles of refractory phase involves technological difficulties, associated with the need for powder protection from oxidation, producing a uniform distribution of components in the mixture, preservation of specified dispersity of the structure and achievement of maximum possible density [2729]. This requires performance of preparatory

Table 2. Main properties of $\mathrm{W}-\mathrm{Cu}$ composite materials (Plansee Group materials [25])

\begin{tabular}{|c|c|c|c|c|c|c|c|c|}
\hline \multirow{2}{*}{ Material } & \multicolumn{2}{|c|}{ Composition, wt.\% } & \multirow{2}{*}{$\begin{array}{l}\text { Density, } \\
\mathrm{g} / \mathrm{cm}^{3}\end{array}$} & \multirow{2}{*}{$\begin{array}{c}\text { Electric } \\
\text { conductivity, } \\
\mathrm{MSm}^{-1}\end{array}$} & \multirow{2}{*}{$\begin{array}{c}\text { Hardness } \\
\text { HV30 }\end{array}$} & \multirow{2}{*}{$\begin{array}{l}\text { Compression } \\
\text { strength, } \mathrm{MPa}\end{array}$} & \multirow{2}{*}{ Melting resistance } & \multirow{2}{*}{ Grain size, $\mu \mathrm{m}$} \\
\hline & W & $\mathrm{Cu}$ & & & & & & \\
\hline $\mathrm{A} 15 \mathrm{Ni}$ & 85 & 15 & 15.7 & 17 & 205 & 250 & Excellent & Up to 50 \\
\hline $\mathrm{A} 20 \mathrm{Ni}$ & 80 & 20 & 15.2 & 18 & 200 & 200 & Very good & Up to 50 \\
\hline $\mathrm{A} 20 \mathrm{NiF}$ & 80 & 20 & 15.2 & 18.5 & 190 & 240 & Same & 2025 \\
\hline FG20 & 80 & 20 & 15.2 & 18.5 & 220 & 350 & Excellent & 48 \\
\hline $\mathrm{A} 25 \mathrm{NiF}$ & 75 & 25 & 14.5 & 21 & 190 & 160 & Good & 2025 \\
\hline A30Ni & 70 & 30 & 14.0 & 23 & 135 & 60 & Same & Up to 50 \\
\hline
\end{tabular}


Table 3. Main properties of $\mathrm{Cr}-\mathrm{Cu}$ composite materials and qualitative evaluation of performance of arcing contacts from them (Plansee Group materials [26])

\begin{tabular}{|c|c|c|c|c|}
\hline \multirow{2}{*}{ Characteristic } & \multicolumn{4}{|c|}{ Material } \\
\hline & CC-98 & CC-75 & CC-70 & CC-57 \\
\hline Cr, wt.\% & 2 & 25 & 30 & 43 \\
\hline $\mathrm{Cu}$, wt.\% & 98 & 75 & 70 & 57 \\
\hline O, wt.\% & 0.15 & 0.65 & 0.675 & 0.7 \\
\hline H, wt.\% & 0.005 & 0.005 & 0.005 & 0.01 \\
\hline $\mathrm{N}$, wt.\% & 0.015 & 0.1 & 0.105 & 0.11 \\
\hline Density, $\mathrm{g} / \mathrm{cm}^{3}$ & 8.70 & 8.05 & 7.90 & 7.60 \\
\hline Hardness $H V 30$ & $110(H B 2.5)$ & 70 & 75 & 85 \\
\hline Electric conductivity & Excellent & Excellent & Very good & Good \\
\hline Melting resistance & o & Very good & Excellent & Excellent \\
\hline Current interruption ability & o & Excellent & Same & Same \\
\hline Interrupt current & o & Good & Very good & $\gg$ \\
\hline Wear resistance & o & Same & Same & $\gg$ \\
\hline Welding resistance & o & Very good & » & » \\
\hline
\end{tabular}

technological operations, such as, for instance, refractory component cladding by interphase active elements to improve adhesion characteristics on matrix-refractory phase interphase [30], longtime high-energy milling with the purpose of mechanical alloying and producing composite pow-
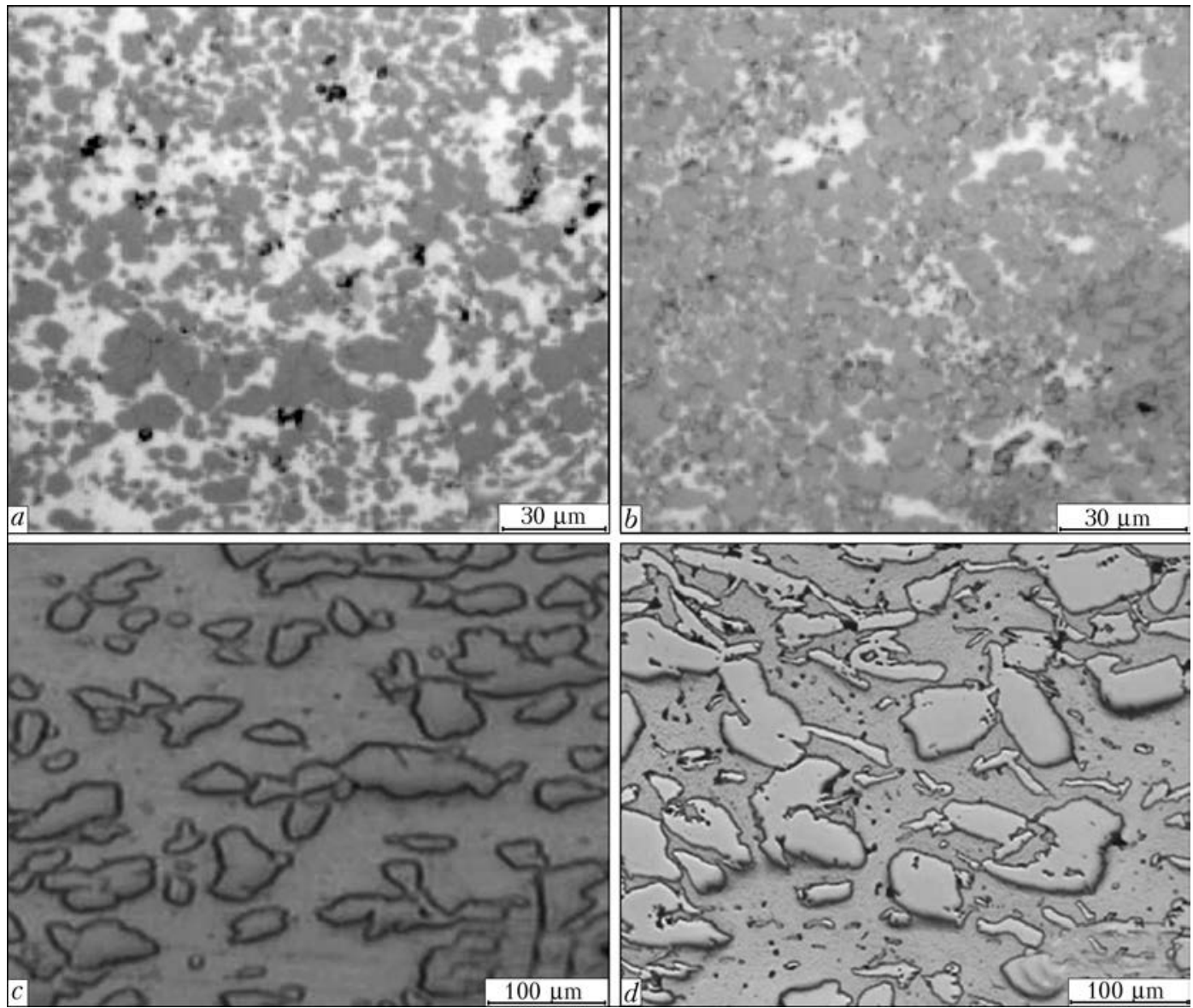

Figure 2. Typical microstructure of DUDUCO SIWODUR 75-1 (Ag/W 25/75) (a), SILMODUR 65 (Ag/Mo 35/65) $(b), \mathrm{CC}-75(\mathrm{Cu} / \mathrm{Cr} 75 / 25)(c)$ and CC-57 HMA $(\mathrm{Cu} / \mathrm{Cr} 57 / 43)(d)$ composite materials [24, 26] 


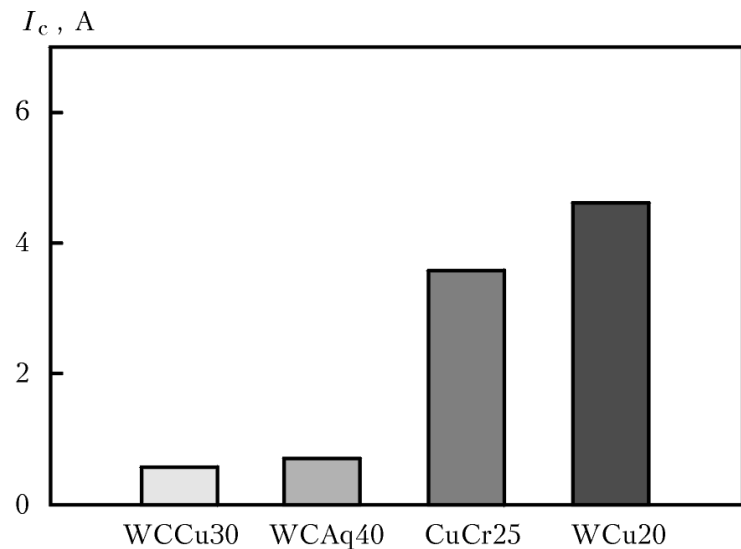

Figure 3. Cut-off current for different contact materials at testing $24 \mathrm{kA} / 24 \mathrm{kV}$ vacuum contactor at maximum current of $30 \mathrm{~A}$ [26]

ders of intermediate composition [31], simultaneous reduction of oxygen-containing compounds of refractory and low-melting components [32].

Selection of composition for contacts also allowed for specific requirements, arising from service conditions of contact-parts. In particular, to switch-off high currents in vacuum, the material of arcing contacts should have minimum content of gas-forming impurities, in particular, oxygen, nitrogen and hydrogen (see Table 3). By changing CM composition, emission properties of the contacts can be controlled, in order to ensure current cutting-off near zero value ( $\mathrm{Fi}$ gure 3).

The disadvantages of this CM class consist in that their machinability deteriorates with increase of refractory component content, and with increase of low-melting component content, the tendency to welding at short-circuiting currents becomes stronger. Moreover, the environments, in which arc extinguishing takes place, should be taken into account. So, at operation of $\mathrm{Ag}-\mathrm{W}$ contact in oxygen-containing environments silver tungstates $\left(\mathrm{Ag}_{2} \mathrm{WO}_{2}\right)$ form on their surface that increases the contact resistance [33]. In [34] it is shown that in the presence of weak electro-

Table 4. Technical characteristics of Elkonite composite materials of CMW Inc. (USA) [38]

\begin{tabular}{|c|c|c|c|c|c|c|}
\hline \multirow{2}{*}{ Elkonite materials } & \multirow{2}{*}{ Composition, wt.\% } & \multirow{2}{*}{ Density, $\mathrm{g} / \mathrm{cm}^{3}$} & \multicolumn{2}{|c|}{ Specific electric conductivity } & \multirow{2}{*}{$\begin{array}{l}\text { Ultimate bending } \\
\text { strength, MPa }\end{array}$} & \multirow{2}{*}{$\begin{array}{c}\text { Hardness } \\
\quad H R B\end{array}$} \\
\hline & & & $\%$ IACS & at $20^{\circ} \mathrm{C}, \mathrm{W} /(\mathrm{m} \cdot \mathrm{K})$ & & \\
\hline $\begin{array}{c}1 \mathrm{~W} 3 \\
3 \mathrm{~W} 3 \\
5 \mathrm{~W} 3 \\
10 \mathrm{~W} 3 \\
10 \mathrm{~W} 53 \\
30 \mathrm{~W} 3 \\
\end{array}$ & $\begin{array}{l}55 \mathrm{~W} / 45 \mathrm{Cu} \\
68 \mathrm{~W} / 32 \mathrm{Cu} \\
70 \mathrm{~W} / 30 \mathrm{Cu} \\
75 \mathrm{~W} / 25 \mathrm{Cu} \\
75 \mathrm{~W} / 25 \mathrm{Cu} \\
80 \mathrm{~W} / 20 \mathrm{Cu}\end{array}$ & $\begin{array}{l}12.50 \\
13.93 \\
14.18 \\
14.84 \\
14.79 \\
15.56 \\
\end{array}$ & $\begin{array}{l}53 \\
50 \\
48 \\
43 \\
28 \\
41\end{array}$ & $\begin{array}{l}310 \\
280 \\
280 \\
260 \\
150 \\
250\end{array}$ & $\begin{array}{c}758 \\
896 \\
965 \\
1030 \\
1380 \\
1170 \\
\end{array}$ & $\begin{array}{c}77 \\
90 \\
95 \\
98 \\
109 \\
103 \\
\end{array}$ \\
\hline $\begin{array}{l}\text { TCS } \\
\text { TC10 } \\
\text { TC20 }\end{array}$ & $\begin{array}{l}50 \mathrm{WC} / 50 \mathrm{Cu} \\
56 \mathrm{WC} / 44 \mathrm{Cu} \\
70 \mathrm{WC} / 30 \mathrm{Cu}\end{array}$ & $\begin{array}{l}11.26 \\
11.64 \\
12.65\end{array}$ & $\begin{array}{l}45 \\
42 \\
30\end{array}$ & $\begin{array}{l}290 \\
280 \\
240\end{array}$ & $\begin{array}{l}1100 \\
1240 \\
1380\end{array}$ & $\begin{array}{c}94 \\
100 \\
H R C 37\end{array}$ \\
\hline
\end{tabular}

Table 5. Technical properties of Cu-based dispersion-strengthened composite materials of Discom-Welding (Russia) [40]

\begin{tabular}{|c|c|c|c|c|c|c|c|}
\hline \multirow{3}{*}{ Material characteristics } & \multicolumn{7}{|c|}{ Material type } \\
\hline & \multicolumn{2}{|c|}{$\mathrm{Cu}-\mathrm{Al}-\mathrm{C}-\mathrm{O}$} & \multicolumn{4}{|c|}{$\mathrm{Cu}-\mathrm{Ti}-\mathrm{C}-\mathrm{O}$} & \multirow{2}{*}{$\frac{\mathrm{Cu}-\mathrm{Al}-\mathrm{Ti}-\mathrm{C}-\mathrm{O}}{\mathrm{C} 16.404}$} \\
\hline & C16.101 & C16.106 & C16.201 & C16.202 & C16.204 & $\mathrm{C} 16.205$ & \\
\hline Density, $\mathrm{g} / \mathrm{cm}^{3}$ & 8.70 & 8.57 & 8.69 & 8.55 & 8.67 & 8.55 & 8.65 \\
\hline Hardness $H B 5 / 750 / 30$ & 185 & 140 & 159 & 147 & 218 & 228 & 193 \\
\hline Electric conductivity, \% IACS & 50 & 85 & 73 & 79 & 56 & 55 & 65 \\
\hline Heat conductivity, $\mathrm{W} /(\mathrm{m} \cdot \mathrm{K})$ & 185 & - & 302 & 305 & 265 & 230 & 271 \\
\hline Ultimate compressive strength, $\mathrm{MPa}$ & 1010 & 1410 & 1170 & 1040 & 1060 & 1070 & 955 \\
\hline Relative shrinkage to fracture, $\%$ & 36 & 59 & 45 & 42 & 27.5 & 26.5 & 30 \\
\hline $\begin{array}{l}\text { Ultimate tensile strength: } \\
\text { at } 20^{\circ} \mathrm{C}\end{array}$ & 717 & 492 & 490 & 510 & 740 & 785 & 700 \\
\hline at $500{ }^{\circ} \mathrm{C}$ & 154 & - & 118 & 128 & 199 & 233 & 220 \\
\hline $\begin{array}{l}\text { Relative elongation, } \% \text { : } \\
\text { at } 20{ }^{\circ} \mathrm{C}\end{array}$ & 8.7 & 15.0 & 17.0 & 10.2 & 8.7 & 6.5 & 10.9 \\
\hline at $500{ }^{\circ} \mathrm{C}$ & 5.2 & - & 3.2 & 6.5 & 5.1 & 4.0 & 7.3 \\
\hline Recrystallization temperature, ${ }^{\circ} \mathrm{C}$ & 930 & 870 & 930 & 880 & 960 & 970 & 940 \\
\hline
\end{tabular}


magnetic fields, arising, for instance, at opening of $\mathrm{Ag}-\mathrm{W}$ arcing contacts, formation of the socalled Taylor cones is observed on the tungsten surface, which increases the breakdown probability after arc re-striking. It is supposed that surface tension of liquid tungsten in an oxygencontaining environment can have a value lower by several orders of magnitude than that of tungsten in vacuum, as such experiments with other metals ( $\mathrm{Ta}, \mathrm{Mo}, \mathrm{Nb}, \mathrm{Cu}$ ) in air and with tungsten in vacuum did not reveal the presence of Taylor cones. Ag-Mo CM are characterized by a more stable contact resistance in air, compared to $\mathrm{Ag}-$ W CM, owing to the fact that molybdenum oxides are less stable, and the effect of working layer surface self-cleaning occurs during current switching.

In welding engineering $\mathrm{Cu}$-based $\mathrm{PCM}$ are a special material group, often used in flash-butt and resistance butt welding of mould inserts, in spot welding of ferrous metals and stainless steel, projection welding of casting moulds, etc. In the general case, welding electrodes should have high heat- and electric conductivity, good high-temperature strength, hardness and recrystallization temperature, as well as low susceptibility to mass transfer through electrode-part contact. Coldworked copper or its alloys with additives of $\mathrm{Cr}$, $\mathrm{Cd}, \mathrm{Ni}, \mathrm{Be}, \mathrm{Si}$, etc. (bronzes) often meet these requirements [35, 36].

However, in welding of low-deformable metals with low conductivity, different thickness, dissimilar or thick-walled materials, etc., there is a need for electrodes of higher hardness, strength and oxidation resistance in combination with relatively low electric conductivity $(\sim 75 \%$ of copper).

Combined electrodes are often used under such conditions, consisting of electrode-insert from refractory metal (W, Mo) or CM on its base, placed into a copper base with cooling system. Such a design provides an essentially longer service life, compared to solid copper electrodes. W (WC)$\mathrm{Cu} \mathrm{CM}$ with 55 wt.\% and greater content of refractory component are often used for welding electrodes. This type of $\mathrm{CM}$ are applied also as electrodes for electroerosive machining, and they are sometimes called by a general term of Elkonite [37, 38]. By varying the composition, it is possible to essentially increase CM strength, while preserving a high level of electric conductivity (Table 4).

A relatively new class for resistance welding electrodes are dispersion-strengthened materials based on powdered copper with dispersed in it refractory phase particles: oxides and carbides

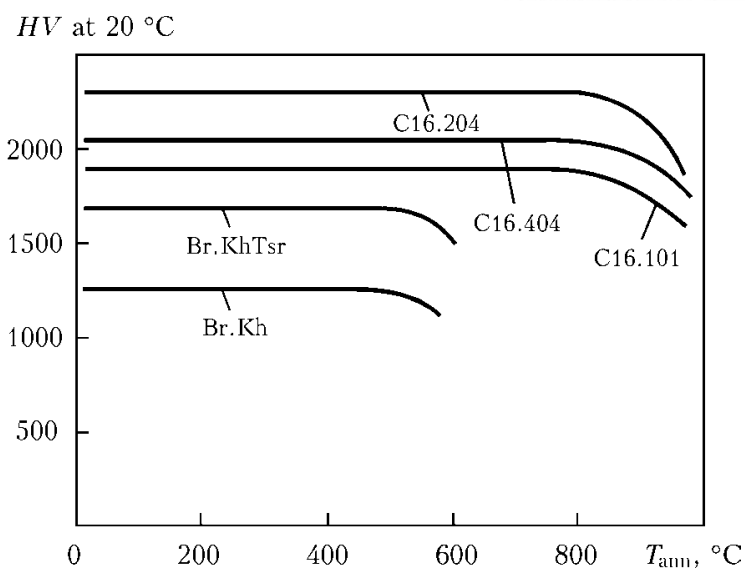

Figure 4. Change of hardness of various $\mathrm{Cu}$-based materials depending on annealing temperature [40]

$\left(\mathrm{Al}_{2} \mathrm{O}_{3}, \mathrm{TiO}_{2}, \mathrm{Cr}_{2} \mathrm{O}_{3}, \mathrm{SiO}_{2}, \mathrm{SiC}\right.$, etc.) [39-41]. Application of the method of high-energy powder milling with mechanical alloying of copper by oxides enabled producing CM with a high level of strength characteristics and recrystallization temperature, close to copper melting temperature (Table 5). Thermal stability and dispersity of oxides provides higher oxidation resistance of dispersion-strengthened CM, compared to $\mathrm{Cr}-$ and $\mathrm{Cr}-\mathrm{Zr}$ bronzes (Figure 4).

\section{Conclusions}

Powdered composite materials of metal-matrix type, based on copper with refractory filler, belong to the class of pseudoalloys and efficiently operate under the conditions of high temperatures, mechanical and electroerosive wear and impact of various media. Owing to uniqueness of their properties, these materials are used for production of arcing contacts of high-voltage switches and for manufacturing welding electrodes for resistance welding.

The main technological production schemes applying powder metallurgy methods include preliminary mixing of powders of initial components of intermediate or final composition with their subsequent sintering at temperatures below or above the melting temperature of low-meting component. Manufacture of nanodispersed CM of this class involves certain difficulties, arising from the need for protecting powders from oxidation, achieving a uniform distribution of components in the mixture, preserving the dispersed structure, and achieving maximum possible density.

A relatively new class for resistance welding electrodes are dispersion-strengthened materials based on powdered copper, containing dispersed oxides and carbides $\left(\mathrm{Al}_{2} \mathrm{O}_{3}, \mathrm{TiO}_{2}, \mathrm{Cr}_{2} \mathrm{O}_{3}, \mathrm{SiO}_{2}\right.$, $\mathrm{SiC}$, etc.), with increased level of strength and oxidation resistance. 
1. (1978) Composite materials. Vol.3: Application of composite materials in engineering. Moscow: Mashinostroenie.

2. Tuchinsky, L.I. (1986) Composite materials produced by impregnation method. Moscow: Metallurgiva.

3. (1990) Composite materials: Refer. Book. Ed. by V.V. Vasiliev, Yu.M. Tarnopolsky. Moscow: Mashinostroenie.

4. Gnesin, G.G., Dubok, V.A., Braterskaya, G.N. et al (1981) Sintered materials for electrical engineering and electronics: Refer. Book. Moscow: Metallurgiya.

5. Evdokunin, G.A., Tiler, G. (2000) Modern vacuum switching equipment of medium voltage. St.-Petersburg: M.P. Sizov Publ.

6. Vacuum switching equipment and components for medium voltage networks. Siemens. http: //w3.siemens.com / powerdistribution / global/SiteCollection Documents / en / mv /indoor-devices / vacuum-switchi ng-technology-and-components_ru.pdf

7. Slade, P.G. (1998) Electric contacts for power interruption: A review. In: Proc. of 19th Int. Conf. on Electric Contact Phenom. (Nuremberg, Germany, 1998), 239-245.

8. Contact materials for electrical engineering. Electrical contacts Wiki. http://www.electrical-contactswiki.com/index.php/Contact_Materials_for_Electri cal_Engineering

9. Bregel, T., Kraussvogt, W., Michal, R. et. al (1991) On the application of $\mathrm{W} / \mathrm{Cu}$ materials in the fields of power engineering and plasma technology. IEEE Transact. on Copmonents Hybrids and Manufact. Technology, 14, 8-13.

10. Namitokov, K.K. (1978) Electroerosion phenomena. Moscow: Energiya.

11. Minakova, R.V., Khomenko, E.V., Kopylova, G.E. et al. (2012) Secondary structure in working layer of electrical contacts from composite materials and their functional properties. In: Electrical contacts and electrodes, 38-47. Kiev: IPMS.

12. Livshits, B.G. (1980) Physical properties of metals and alloys. Moscow: Metallurgiya.

13. Fedorchenko, I.M., Frantsevich, I.N., Radomyselsky, I.D. (1985) Powder technology: Materials, technology, properties, fields of application: Refer. Book. Kiev: Naukova Dumka.

14. Zakharov, A.M. (1990) Constitutional diagrams of binary and ternary systems. Moscow: Metallurgiva.

15. Plansee Group. Fields of competence. Technologies http: / / www.plansee.com / en / About-us-Expertise-T echnology-118.htm

16. Hula, R.Ch., Edmaier, Ch. (2000) Silver coated tungsten carbide powders for composite electrical contact application. Powder Metallurgy Progress, 9(1) 34-41; http: / / www.imr.saske.sk / $\mathrm{pmp} /$ is sue/1-2009/PMP Vol09 No1 p034-041.pdf

17. Slade, P. (2007) The vacuum interrupter. Theory, design and application. London: Taylor and Francis Books.

18. Najdich, Yu.V. (1972) Contact phenomena in metal melts. Kiev: Naukova Dumka.

19. Avraamov, Yu.S., Shlyapin, A.D. (1999) Novel composite materials based on immiscible components. Producing, structure and properties. Moscow: MGU.

20. Smaga, N.N., Yudin, B.A., Markov, E.V. (1965) Method of producing and test results of fine-dispersed metal-ceramic compositions for contacts of electric apparatuses. In: Electrical metal-ceramic products. Moscow: VNIIEM

21. Kornienko, V.P., Yudin, B.A., Kolesnikov, V.N (1977) Fine-grained composite contacts for low-voltage equipment. In: Electrical contacts and electrodes, 70-79. Kiev: Naukova Dumka.
22. Rieder, W.F., Schussek, M., Glatzle, W. et al. (1989) The influence of composition and Cr-particle size of $\mathrm{Cu} / \mathrm{Cr}$ contacts on chopping current, contact resistance and breakdown voltage in vacuum interrupters. IEEE Transact. on Components Hybrids and Manufact. Techology, 12(2), 273-283.

23. Laptiev, A., Tolochyn, O., Khomenko, O. et al. (2014) Solid state impact sintering in vacuum of composites based on copper and silver. In: Proc. of 27th Conf. on Electrical Contacts (Dresden, Germany, June 22-26, 2014), 457-462.

24. Tungsten and molybden based materials. Powered by Doduco. http: www.electrical-contacts-wiki.com index.php/Tungsten_and_Molybdenum_Based_Mate rials

25. Plansee Group. http://www.plansee.com/ru/Products-Electrical-contacts-Tungsten-copper-WCu-58.htm

26. Plansee Group. http:/ www.plansee.com/ru/Products-Electrical-contacts-Copper-chromium-CuCr-59.htm

27. Najdich, Yu.V., Lavrinenko, I.A., Evdokimov, V.A. (1974) Study of compaction process in liquid-phase sintering under pressure in tungsten-copper system. Poroshk. Metallurgiya, 1, 34-39.

28. Panichkina, V.V., Sirotyuk, M.M., Skorokhod, V.V. (1982) Liquid-phase sintering of high-dispersed tungsten-copper mixtures. Ibid., 6, 27-31.

29. Grill, R., Klausler, P., Mueller, E.-H. et al. (2005) WC Ag contact materials with improved homogeneity. In: Proc. of 16th Int. Plansee Seminar (Reutte, Austria), 200-211.

30. Amirjan, M., Zangeneh-Madar, K., Parvin, N. (2009) Evaluation of microstructure and contiguity of $\mathrm{W} / \mathrm{Cu}$ composites prepared by coated tungsten powders. Refractory Metals and Hard Materials, 27, 729-733.

31. Dorfman, L.P., Scheithauer, M.J., Paliwal, M. et al. Alloy for electrical contacts and electrodes and method of making. Pat. US 6375708 B1. Publ. 23.04.2002

32. Moon-Hee Hong, Ja-Ho Choi, Seoung Lee et al. $W-$ $\mathrm{Cu}$ alloy having homogeneous micro-structure and manufacturing method thereof. Pat. US 7172725 B2. Publ. 6.02.2007.

33. Wingert, P.S. (1993) The effect of Ni on the switching performance of AgW based on contacts. In: Proc. of 39th IEEE Holm Conf., 111-115.

34. Batrakov, A.V., Popov, S.A., Proskurovsky, D.I. (1996) Electrodynamic phenomena in exploding tungsten electrical contacts. In: Proc. of $42 n d$ IEEE Holm Conf., 129-136.

35. Gulyaev, A.I. (1985) Technology and equipment for resistance welding. Moscow: Mashinostroenie.

36. (1986) Technology and equipment of resistance welding. Moscow: Mashinostroenie.

37. Toshiba materials Co Ltd. Elkonite. http:/ / www. toshiba-tmat.co.jp/eng/list/ta elc.htm

38. Contacts metals welding. Typical properties of Elkonite materials. http://www.tjsnow.com/supplies/ $\mathrm{cmw} / \mathrm{w} 49 \mathrm{f}$.pdf

39. Kos, M., Fercec, J., Bruncko, M. et al. (2014) Pressing of partially oxide-dispersion-strengthened copper using the ECAP process. Mater. and Technology, 48, Issue 3, 370-384.

40. Discom-welding. Nanostructural materials and their products. http: / discom-svarka.ru/dukm

41. Anoshin, V.A., Ilyushenko, V.M., Minakova, R.V. (2010) Heat-resistant materials based on copper. Method of producing. Properties. Applications. In: Transact. of IPMS, 212-218.

Received 27.04.2015 